\title{
Dynamics of redox changes of iron caused by light-dark variations in littoral sediment of a freshwater lake
}

\author{
SIMONE GERHARDT ${ }^{1}$, ANDREAS BRUNE ${ }^{1,2}$ \\ and BERNHARD SCHINK ${ }^{1, *}$ \\ ${ }^{1}$ Fachbereich Biologie, LS Mikrobielle Ökologie, Universität Konstanz, 78457 Konstanz, Germany; \\ ${ }^{2}$ Present address: Abteilung Biogeochemie, Max-Planck-Institut für terrestrische Mikrobiologie \\ Karl-von-Frisch-Strasse, 35043 Marburg, Germany; *Author for correspondence (e-mail: \\ Bernhard.Schink@uni-konstanz.de; phone: +49-7531-882140; fax: +49-7531-884047)
}

Received 1 March 2004; accepted in revised form 13 October 2004

Key words: Ferric iron, Ferrous iron, Freshwater sediment, Iron cycle, Light, Oxygen

Abstract. Depth profiles of oxygen concentration and the redox status of acid-extractable iron were measured in littoral sediment cores of Lake Constance incubated under a light-dark regimen of $12 \mathrm{~h}$. While oxygen penetrated to $3.4 \pm 0.2 \mathrm{~mm}$ depth in the dark, photosynthetic oxygen production shifted the oxic-anoxic interface down to $4.0 \pm 0.2 \mathrm{~mm}$ or $5.9 \pm 1.6 \mathrm{~mm}$ depth, at low or high light intensity, respectively, and caused a net oxygen efflux into the water column. After a light-dark or dark-light transition, the oxygen concentration at the sediment surface reached a new steady state within about $20 \mathrm{~min}$. The redox state of the bioavailable iron was determined in $1-\mathrm{mm}$ slices of sediment subcores. After a dark period of $12 \mathrm{~h}, 85 \%$ of the acid-extractable iron $\left(10.5 \mu \mathrm{mol} \mathrm{cm}{ }^{-3}\right.$ total $)$ in the uppermost $8 \mathrm{~mm}$ was in the reduced state. Within $12 \mathrm{~h}$ at low or high light intensity, the proportion of ferrous iron decreased to 82 or $75 \%$, respectively, corresponding to net rates of iron oxidation in the range of 244 and $732 \mathrm{nmol} \mathrm{cm} \mathrm{cm}^{-3} \mathrm{~h}^{-1}$, respectively. About 55 or $82 \%$ of the iron oxidation at low or high light intensity occurred in the respective oxic zone of the sediment; the remaining part was oxidized in the anoxic zone, probably coupled to nitrate reduction. The areal rates of iron oxidation in the respective oxic layer $\left(21\right.$ or $123 \mathrm{nmol} \mathrm{cm} \mathrm{cm}^{-2} \mathrm{~h}^{-1}$ at low or high light intensity, respectively) would account for 4 and $23 \%$ of the total electron flow to oxygen, respectively. Light changes caused a rapid migration of the oxic-anoxic interface in the sediment, followed by a slow redox reaction of biologically available iron, thus providing temporal niches for aerobic iron oxidizers and anaerobic iron reducers.

\section{Introduction}

The littoral sediment is subject to highly dynamic light conditions. The day-night cycle and irregular clouding influence the distribution, concentration and redox state of dissolved and particulate sediment compounds (Wetzel 2001). Depending on the sediment structure and composition, light can penetrate several millimeters into the sediment (Kühl and Jørgensen 1994), where it fuels oxygenic and anoxygenic photosynthesis and thereby governs the distribution and redox state of oxygen and sulfur compounds (Revsbech et al. 1983; Pfennig and Trüper 1992; Pierson and Castenholz 1992; Trüper and Pfennig 1992; Pierson et al. 1999). Some anoxygenic phototrophs can also oxidize 
ferrous iron and thus could interfere directly with the redox state of iron minerals in the sediment (Widdel et al. 1993; Ehrenreich and Widdel 1994).

In littoral sediments of oligotrophic lakes such as Lake Constance, the oxic zone extends several millimeters into the sediment. In such stratified systems with counter gradients of oxygen and ferrous iron, chemotrophic aerobic iron-oxidizing bacteria (Kucera and Wolfe 1957; Ghiorse 1984) could catalyze ferrous iron oxidation with oxygen and compete with chemical oxygendependent ferrous iron oxidation (Stumm and Morgan 1981). In the dark anoxic sediment layers, ferrous iron can be oxidized by nitrate-reducing bacteria (Straub et al. 1996).

Ferric iron is reduced under anoxic conditions either chemically by sulfide (Peiffer 1994) or humic acids (Szilágyi 1971) or microbially by bacteria (Lovley and Phillips 1986) which might mediate ferric iron reduction by various electron carriers (Lovley et al. 1996; Benz et al. 1998b; Nevin and Lovley 2000; Straub and Schink 2003). Ferrous iron can also be oxidized chemically with nitrite (Moraghan and Buresh 1976), but does so only if nitrite accumulates to concentrations higher than $0.3 \mathrm{mM}$ (Benz et al. 1998a).

The dynamics of oxygen distribution and redox state of sulfur compounds under the influence of the day-night cycle have been studied in detail in the past, mainly in microbial mats and marine littoral sediments (Fründ and Cohen 1992; Garcia-Pichel et al. 1994; Epping and Kühl 2000; Glud et al. 2003), as well as in soft freshwater sediment colonized by epipelic periphyton (Carlton and Wetzel 1986). Following the pattern of the microbially influenced redox chain (Zehnder and Stumm 1988), an increased penetration of oxygen into the sediment during daytime causes a downward shift in the zonation and microbial transformation of the subsequent electron acceptors nitrate, sulfate, and ferric iron. The rate and extent of these changes in redox state in the sediment differ, depending on the solubility and diffusion capacity of the affected compounds, and on the rates of the involved reactions.

Little is known about the kinetics of microbial iron transformations (Roden and Wetzel 2002) because high-resolution analysis of iron oxides is difficult (Cornell and Schwertmann 1996). In the present study, we document the influence of alterations in light intensity on the extent and rates of changes in ferrous and ferric iron distribution in a littoral freshwater sediment, and compare these changes with the simultaneous changes in oxygen distribution.

\section{Materials and methods}

\section{Location and sampling}

Sediment was sampled in the bay 'Obere Güll' next to Mainau Island in the Überlingersee, the Northwestern branch of Lake Constance, Germany, at 1-2 m water depth. The site is influenced by water currents from the Northwest, wave motion, and wind. The sediment was sandy and consisted of 
fine-grained material (mainly below $0.5 \mathrm{~mm}$ particle size), with some lime. Part of the bottom of the bay is covered with macrophytes, Characea ssp. and Potamogeton pectinatus L., but for our experiments vegetation-free sediment devoid of macrophyte roots was used.

Sediment cores of $250 \mathrm{~mm}$ length were taken from aboard a boat with plastic tubes of $80 \mathrm{~mm}$ diameter. Tubes were pushed into the sediment vertically with a modified sediment corer (Tessenow et al. 1977) and pulled up carefully with a rope. During upwards movement, a conical lid on the sampling tube closed to prevent sediment losses. On board, cores were sealed at the bottom with rubber stoppers, capped, and transported to the laboratory within $1.5 \mathrm{~h}$ of collection. There these primary cores were subsampled with cylindrical polypropylene tubes $(200 \mathrm{~mm}$ long, $26 \mathrm{~mm}$ in diameter). Four subsampling tubes were inserted simultaneously into each core down to about $150 \mathrm{~mm}$ depth. After careful removal of the outer tube, subcores were sealed from below and were cleared of the surrounding sediment. Using this method, the sediment stratification remained undisturbed and mixing of the surface sediment was avoided. The subcores in each set of four were found to exhibit only minor differences in their physical and chemical characteristics.

\section{Incubation of the sediment}

Subcores were covered carefully with filtered lake water and incubated in basins under a $150 \mathrm{~mm}$ layer of aerated and filtered lake water, at a constant temperature of $15^{\circ} \mathrm{C}$ in a climate-controlled chamber in which all subsequent experiments were carried out. The basins were illuminated under a 12-h light-dark cycle with a combination of three Osram lamps (Biolux L30W/72; Fluora L30W/77; and Haloline 200,W/R7s) to generate low light intensity of $1.5 \mathrm{klx}\left(25 \mu \mathrm{E} \mathrm{m}^{-2} \mathrm{~s}^{-1}\right)$ at the water surface. In some experiments, additional lamps were used to generate a 10 -fold higher light intensity. Neither the water temperature nor the temperature of the sediment were influenced by the incident light. Subcores were incubated in the basin for $36 \mathrm{~h}$ before the experiments were started.

\section{Microsensor measurements}

Clark-type oxygen microsensors (Revsbech 1989) with tip diameters of $10-15 \mu \mathrm{m}$ and $90 \%$ response times of $<1 \mathrm{~s}$ were constructed and calibrated as previously described (Brune et al. 1995). Microelectrodes were positioned with a manual micromanipulator (MM33; Märzhäuser, Wetzlar, Germany), using a depth increment of $250 \mu \mathrm{m}$; the tip was positioned at the sediment surface with the help of a stereomicroscope. Data were recorded with a millivoltmeter and a chart recorder. 
Oxygen concentrations were calculated from the original data $(\mathrm{mV})$ by dividing by the response $\left(\mathrm{mV} \mathrm{kPa}^{-1}\right)$ of the respective microelectrode and multiplying with the Bunsen absorption coefficient $\left(0.01473 \mathrm{~mol} \mathrm{l}^{-1} \mathrm{~atm}^{-1}\right.$ at $15^{\circ} \mathrm{C}$ ). The oxygen influx into or oxygen efflux out of the sediment was calculated from the gradient of oxygen profiles in the diffusive boundary layer above the sediment using Fick's first law of diffusion. The rate of gross photosynthesis at a specific depth was calculated from the change in oxygen concentration over $30 \mathrm{~s}$ after shifting the light conditions from steady-state conditions at illumination with low light intensity to darkness (Revsbech et al. 1981).

\section{Sediment extraction}

After $12 \mathrm{~h}$ of incubation under the respective conditions, the overlying water was removed carefully from the sediment surface and the sediment subcores were transferred under a $\mathrm{N}_{2}$ atmosphere inside an anoxic chamber. Subcores were fit upright into a device that allowed cutting of the sediment into exact $1-\mathrm{mm}$ slices (Figure 1). Each slice of the uppermost $20 \mathrm{~mm}$ of the sediment was suspended immediately in $25 \mathrm{ml}$ of $1 \mathrm{M} \mathrm{HCl}$ and distributed evenly in the liquid. After $1 \mathrm{~h}$ at room temperature, the suspension was mixed again, and $2 \mathrm{ml}$ was removed and centrifuged for $15 \mathrm{~min}$. The supernatant was used for iron analysis. Cold hydrochloric acid dissolves amorphous iron oxides, carbonates, and replaces metal ions adsorbed to inorganic and organic sediment constituents. Of the crystalline iron oxides such as hematite, magnetite, and goethite, only about $2 \%$ dissolves by this treatment (Chao and Zhou 1983).

Unfiltered pore water was sampled in an anoxic chamber from 1-cm slices of sediment after centrifugation under $\mathrm{N}_{2}$ atmosphere for $30 \mathrm{~min}$ at $12,000 \times g$.

\section{Analysis of iron concentration}

Ferrous iron in acid extracts from each sediment slice or pore water samples was determined using the ferrozine assay (Stookey 1970). Three 50- $\mu$ parallel samples were diluted 10 -fold in $1 \mathrm{M} \mathrm{HCl}$. To each of three further $50-\mu 1$ parallel samples, $450 \mu \mathrm{l}$ of $10 \%(\mathrm{w} / \mathrm{v})$ hydroxylamine hydrochloride in $1 \mathrm{M} \mathrm{HCl}$ was added to reduce ferric iron. After $1 \mathrm{~h}$ of incubation at room temperature, $500 \mu \mathrm{l}$ of $0.1 \%(\mathrm{w} / \mathrm{v})$ ferrozine in $50 \%(\mathrm{w} / \mathrm{v})$ aqueous ammonium acetate solution was added. After $10 \mathrm{~min}$, absorption was measured photometrically at $562 \mathrm{~nm}$, and iron concentrations were calculated via a calibration curve. Samples treated with hydroxylamine hydrochloride gave the total iron content. Differences between total iron and ferrous iron represented the ferric iron content of the extracts. 


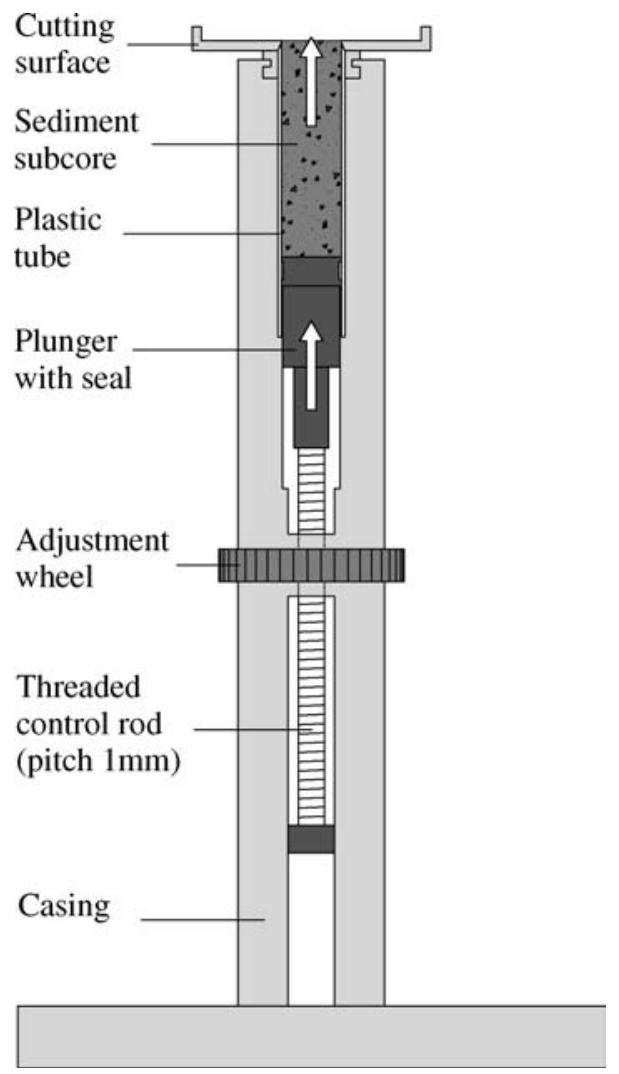

Figure 1. Cutting device used for reproducible preparation of 1-mm slices of sediment subcores.

\section{Replicates and statistics}

All samples used for determination of ferrous and total iron concentration and $95 \%$-confidence interval were analyzed at least in triplicate. Numbers of parallels given in the text describe the number of different sediment cores analyzed in parallel to reproduce the results. Depth profiles of ferrous and total iron concentration $\left(\mu \mathrm{mol} \mathrm{cm} \mathrm{cm}^{-3}\right)$ were measured with $1-\mathrm{mm}$ resolution in the uppermost $20 \mathrm{~mm}$ of the sediment. From these data, the proportion of ferrous iron to total iron (\%) and the ferric iron concentration $\left(\mu \mathrm{mol} \mathrm{cm} \mathrm{cm}^{-3}\right)$ was calculated. Depth profiles were measured after $12 \mathrm{~h}$ incubation in darkness or under low- and high-intensity light. From differences in the ferrous iron content over time rates of iron oxidation or reduction $\left(\mathrm{nmol} \mathrm{cm} \mathrm{cm}^{-3} \mathrm{~h}^{-1}\right.$ ) per 1-mm depth of the respective sediment layer were calculated. Multiplication of these rates with the specific volume gave the electron flow rates (nmol $\mathrm{cm}^{-2} \mathrm{~h}^{-1}$ ) across the surface per 1-mm depth of the respective sediment layer. 


\section{Results}

\section{Effects of light on oxygen profiles}

The depth of oxygen penetration into the sediment increased with the intensity of the incident light. After $12 \mathrm{~h}$ of incubation in the dark, oxygen penetrated down to $3.4 \pm 0.2 \mathrm{~mm}$ depth $(n=5)$. After the same incubation time at low light intensity $\left(25 \mu \mathrm{E} \mathrm{m}^{-2} \mathrm{~s}^{-1}\right)$, corresponding to the light conditions at $2 \mathrm{~m}$ water depth during an overcast day, the oxic-anoxic interface was positioned at $4.0 \pm 0.2 \mathrm{~mm}$ depth $(n=7)$. At high light intensity $\left(250 \mu \mathrm{E} \mathrm{m}^{-2} \mathrm{~s}^{-1}\right)$, corresponding to the light conditions at $2 \mathrm{~m}$ water depth during a bright sunny day, oxygen penetrated down to $5.9 \pm 1.6 \mathrm{~mm}$ depth $(n=2)$. In the dark, the net areal flux of oxygen into the sediment was $47 \pm 30 \mathrm{nmol} \mathrm{cm}^{-2} \mathrm{~h}^{-1}$. During incubation at low or high light intensity, oxygen diffused from the sediment into the overlying water at a rate of $30 \pm 26 \mathrm{nmol} \mathrm{cm} \mathrm{cm}^{-2} \mathrm{~h}^{-1}$ or $157 \pm 69 \mathrm{nmol}$ $\mathrm{cm}^{-2} \mathrm{~h}^{-1}$, respectively. The corresponding maxima of oxygen concentration were $317 \mu \mathrm{M}$ at $0.25 \mathrm{~mm}$ depth, and $530 \mu \mathrm{M}$ at $0.75 \mathrm{~mm}$ depth (Figure 2A). Changes in oxygen concentration at distinct depth in the sediment after transition from darkness to low-light conditions were followed over time. Results give the oxygen concentrations over time (Figure 3) or with depth (Figure 4). From these data, rates of gross photosynthesis were calculated, the depth profile of gross photosynthesis is given in Figure 2B. At the sediment surface, the oxygen content was only slightly influenced by dark-light changes. Deeper in the sediment, the oxygen concentration changed dramatically, causing oversaturation at $0.25-2 \mathrm{~mm}$ depth during illumination. The changes in oxygen
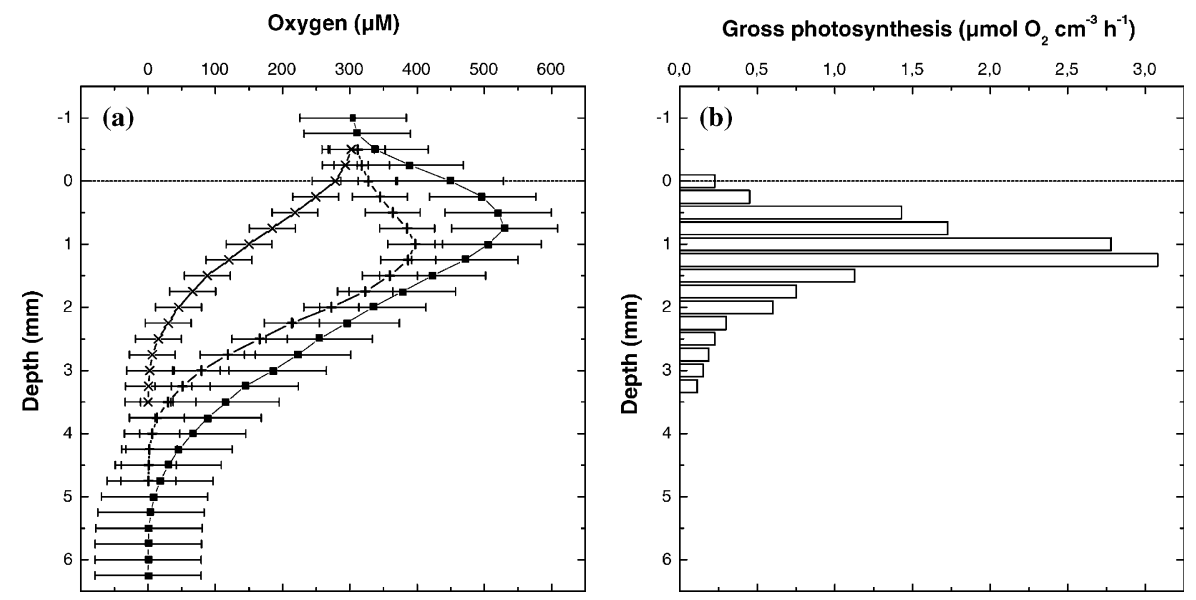

Figure 2. (a) Depth profiles of oxygen concentration $(\mu \mathrm{M})$ in littoral sediment at steady state after $12 \mathrm{~h}$ of incubation in the dark $(\times, n=5)$, after illumination with low-intensity light $(+, n=3)$, or with high-intensity light $(\boldsymbol{\square}, n=2)$; mean values and $95 \%$-confidence interval. (b) Rates of gross photosynthesis ( $\mu \mathrm{mol} \mathrm{cm}{ }^{-3} \mathrm{~h}^{-1}$; bars). The sediment surface is indicated by a dashed line. 


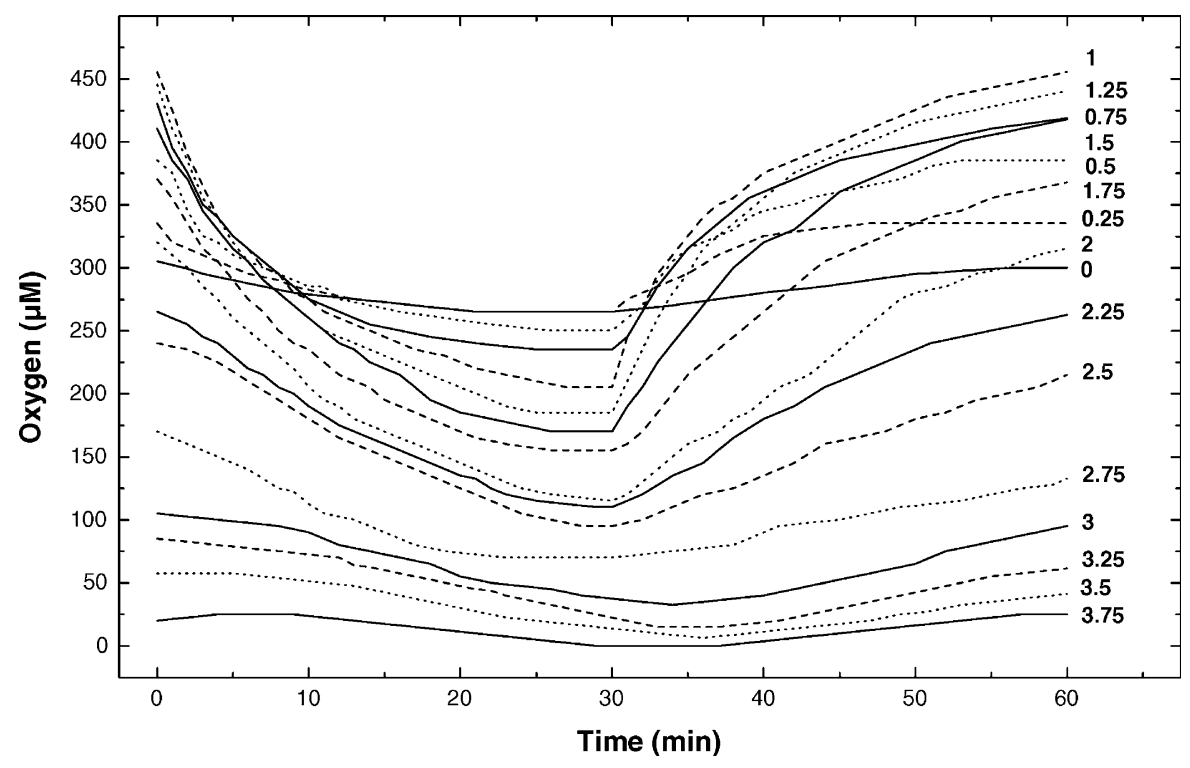

Figure 3. Changes in oxygen concentration $(\mu \mathrm{M})$ at distinct depth layers in littoral sediment over time after darkening (1-30 $\mathrm{min}$ ) and after illumination (31-60 min). Numbers at the curves give the depth of measurement in the sediment $(0-3.75 \mathrm{~mm})$.
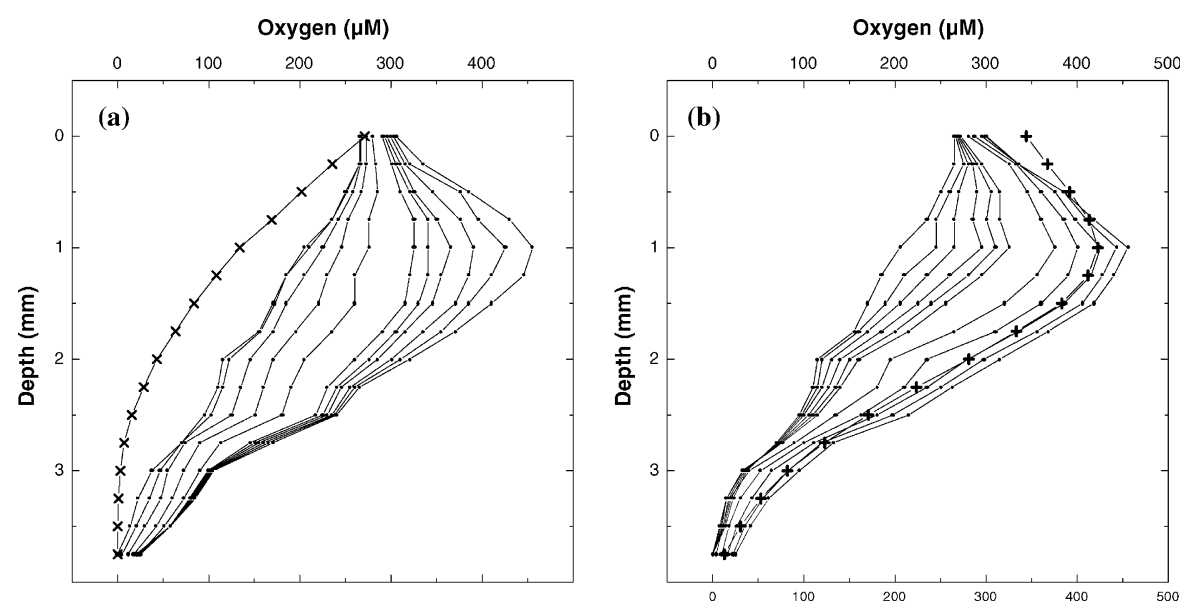

Figure 4. Oxygen depth profiles $(\mu \mathrm{M})(\bullet)$ in littoral sediment, measured immediately, and 1, 2, 3, $4,5,10,15,20,25$, and $30 \mathrm{~min}$ after changing from light to dark (a, from the right to the left) or from dark to light (b, from the left to the right). Steady-state conditions were measured after $12 \mathrm{~h}$ of incubation in the dark $(x)$ or in the light $(+)$.

concentration after the change in illumination were fastest during the first $5 \mathrm{~min}$, and slowed down afterwards. Down to $3.25 \mathrm{~mm}$ depth, oxygen decreased immediately after changing from light to dark, and rates for gross 
photosynthesis were calculated for these depths. Gross photosynthesis was highest at $1.25 \mathrm{~mm}$ depth with $3 \mu \mathrm{mol} \mathrm{cm} \mathrm{c}^{-3} \mathrm{~h}^{-1}$; the mean value was $0.9 \mu \mathrm{mol} \mathrm{cm}{ }^{-3} \mathrm{~h}^{-1}$. From this value, an oxygen flow rate directed towards the overlying water of $161 \mathrm{nmol} \mathrm{cm} \mathrm{cm}^{-2} \mathrm{~h}^{-1}$ was calculated. After switching from light to dark, the oxygen concentration at the sediment surface did not change any more after $21 \mathrm{~min}$; with increasing depth, it took several minutes longer until a new steady state was reached.

\section{Content and speciation of iron}

Subcores from primary sediment cores sampled in different seasons were analyzed to check for temporal differences in ferrous and ferric iron concentration. The porewater in the uppermost $20 \mathrm{~mm}$ of the sediment contained on average $200 \pm 70 \mu \mathrm{M}$ ferrous iron and $50 \pm 20 \mu \mathrm{M}$ ferric iron $(n=11)$. In the solid phase of the sediment on average $9.9 \pm 1.1 \mu \mathrm{mol} \mathrm{cm}{ }^{-3}$ ferrous iron and $3.8 \pm 1.2 \mu \mathrm{mol} \mathrm{cm}{ }^{-3}$ ferric iron were measured $(n=14)$. All cores showed an increasing proportion of ferrous iron with depth (Figure 5). The average proportion of ferrous iron to total iron varied throughout the study period, with $93 \%$ in December, $63 \%$ in May, and $84 \%$ in September. For the uppermost $3 \mathrm{~mm}$ of the sediment, these seasonal differences were even more expressed, with 87,48 and $72 \%$, respectively. The ferrous iron content in the sediment at 11-20 mm depth was 3\% higher than that in the uppermost $10 \mathrm{~mm}$

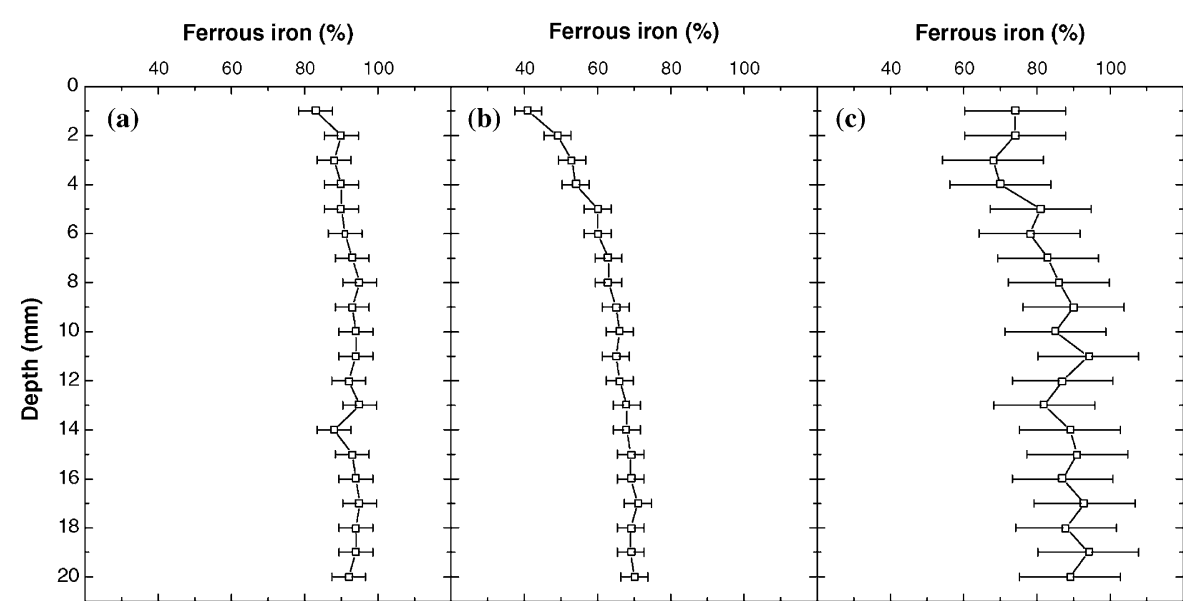

Figure 5. Depth profiles of the proportion of ferrous iron to total iron in littoral sediment. Mean values and $95 \%$ confidence intervals were calculated from concentration measurements of ferrous iron and total iron. Iron concentrations were measured after 0 days in all cases, and after 7 (a), 14 (b) or 27 days (c) of incubation. Sediment subcores were sampled and analyzed in December 2001 $(n=2)$, May $2002(n=8)$ and August/September $2002(n=4)$. 
of the sediment in December, $19 \%$ higher in May, and $12 \%$ higher in September.

We checked sediment collected at the same time but at different locations within $20 \mathrm{~m}$ distance for spatial heterogeneities in ferrous and ferric iron distribution. The proportion of ferrous iron to total iron in these sediment cores did not differ significantly.

To check for changes in ferrous iron and ferric iron concentration caused by the incubation conditions, one or two subcores of the same sediment core were analyzed immediately after core preparation; others after 7 days (first control experiment, $n=2$ ), 14 days (second control experiment, $n=8$ ) or 27 days (third control experiment, $n=4$ ) of incubation. No significant differences in ferrous and total iron content were found between sediment subcores after 0 days and after 7, 14 or 27 days of incubation although the $95 \%$-confidence interval changed from $\pm 5 \%$ to $\pm 4 \%$ and to $\pm 14 \%$, respectively. Thus, the incubation conditions had no effect on the proportion of ferrous to total iron. In the second control experiment, additional sediment subcores of a different set were analyzed after 0 and 14 days of incubation. No significant differences between the ferrous and total iron content of sediment from different subcore sets were detected, either immediately or after 14 days of incubation.

\section{Effects of light on the redox state of the iron pool}

Concentrations of ferrous iron, ferric iron, and total iron were measured in sediment subcores of the same set after $12 \mathrm{~h}$ of incubation under the described conditions in the dark or under low- or high-intensity light (Figure 6). The sediment contained on average $9.2 \pm 0.3 \mu \mathrm{mol} \mathrm{cm}{ }^{-3}$ ferrous and $1.3 \pm 0.2 \mu \mathrm{mol} \mathrm{cm}{ }^{-3}$ ferric iron $(n=6)$. This corresponds to a total electron pool of $10.5 \pm 0.2 \mu \mathrm{mol} \mathrm{cm}{ }^{-3}$ in the iron phase that can be subject to redox reactions. From these data the proportion of ferrous iron to total iron was calculated (Figure 7). The ferrous iron content in the sediment from the surface down to $8 \mathrm{~mm}$ depth decreased with incident light intensity. In the dark the ferrous iron content was $85 \%$ at $1-8 \mathrm{~mm}$ depth; after incubation under low-intensity light it was $82 \%$, i.e. $3 \%$ lower; and after incubation under high-intensity light, it decreased further to $75 \%$. With increasing light intensity, the differences in ferrous iron content were statistically significant further down in the sediment. Changes from dark to low light intensity caused significant changes in ferrous iron content down to $4 \mathrm{~mm}$ depth, from low to high light intensity down to $6 \mathrm{~mm}$ depth, and from dark to high light intensity down to $8 \mathrm{~mm}$ depth. The rate of iron oxidation was higher the more reduced the iron compounds were initially, and the more intense the incident light was. The changes from dark to low light intensity caused oxidation of $244 \mathrm{nmol} \mathrm{cm}{ }^{-3} \mathrm{~h}^{-1}$ electrons in the iron phase, from dark to high light

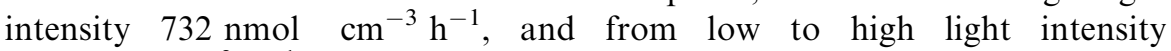
$488 \mathrm{nmol} \mathrm{cm}^{-3} \mathrm{~h}^{-1}$. After incubation in the dark, the ferrous iron content was 


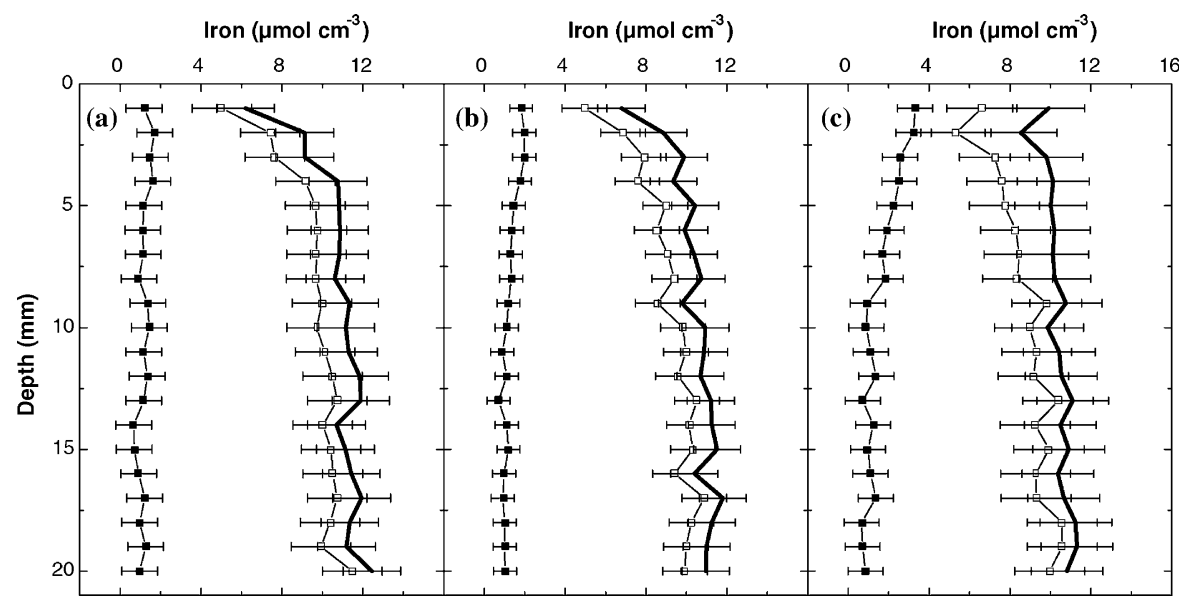

Figure 6. Depth profiles of ferric ( $\square)$, ferrous iron ( $\square$ ) and total iron (-) concentration $\left(\mu \mathrm{mol} \mathrm{cm}{ }^{-3}\right)$ in littoral sediment. The mean values and $95 \%$-confidence interval are calculated from two independent experiments with three single measurements each. Measurement after $12 \mathrm{~h}$ of incubation in the dark (a) or under light of low (b) or high intensity (c).

Ferrous iron (\%)

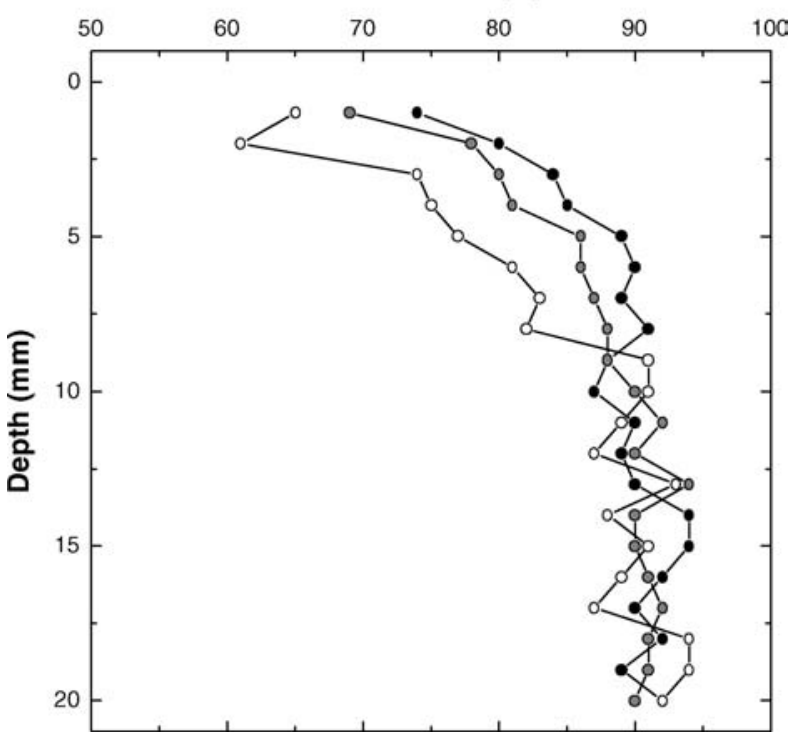

Figure 7. Depth profiles of the proportion of ferrous iron to total iron in littoral sediment, calculated from concentration measurements after $12 \mathrm{~h}$ of incubation in the dark (black dots) or in light of low (grey dots) or high intensity (white dots).

sevenfold higher than the ferric iron content, fivefold higher after incubation under low-intensity light, and threefold higher after incubation under highintensity light. 
Under low-light conditions, $55 \%$ of total iron oxidation in the sediment from 1 to $8 \mathrm{~mm}$ depth occurred in the oxic zone down to $4 \mathrm{~mm}$ depth. Under high-intensity light, $82 \%$ of total iron oxidation was observed in the oxic zone down to $6 \mathrm{~mm}$ depth in the sediment. At $1-8 \mathrm{~mm}$ depth, 45 or $18 \%$ of total iron oxidation took place in the anoxic zone below 4 or $6 \mathrm{~mm}$ depth, respectively. The electron release rate owing to aerobic iron oxidation down to $4 \mathrm{~mm}$ depth was $21 \mathrm{nmol} \mathrm{cm} \mathrm{cm}^{-2} \mathrm{~h}^{-1}$ under low-intensity light and down to $6 \mathrm{~mm}$ depth was $123 \mathrm{nmol} \mathrm{cm} \mathrm{cm}^{-2} \mathrm{~h}^{-1}$ at high-intensity light. These electrons released by iron oxidation in the oxic zone of the sediment incubated under low or high light intensity accounted for 4 or $23 \%$, respectively, of the about $500 \mathrm{nmol} \mathrm{cm}{ }^{-2} \mathrm{~h}^{-1}$ electrons consumed by complete reduction of the oxygen remaining in the sediment during incubation under low-intensity light.

\section{Discussion}

The present study demonstrates that changes in light intensity result in a rapid shift of the position of the oxic-anoxic interface in the sediment and in a slower, diurnal redox cycle of the biologically available iron. The differences in the dynamics of these processes provide niches for aerobic and anaerobic iron oxidizers and for iron reducers in a dynamically changing environment.

\section{Ecological consequences of dynamic fluctuations in oxygen concentration and iron redox state}

Nightfall or reduced light intensity during the day caused by clouding shift the oxic-anoxic interface upwards, which places ferric iron into a now anoxic surrounding. In this situation, ferric iron acts as an electron sink and is reduced - either directly by ferric iron-reducing bacteria (Nealson and Saffarini 1994; Lovley 1997; Thamdrup 2000), or chemically by reduced electron carriers (reduced humic compounds, quinones, or sulfur compounds) generated by true iron reducers, fermenting bacteria, and sulfate- and sulfur-reducing bacteria (Lovley et al. 1996; Benz et al. 1998b).

Increasing light intensity in the morning or the breaking-up of a cloud cover stimulate photosynthetic oxygen production and shift the oxic-anoxic interface downwards, exposing ferrous iron to a now oxic surrounding. In this situation, ferrous iron acts as an electron source for chemical or microbially catalyzed oxidation reactions. In the oxic zone of the sediment, reduced iron can be oxidized by aerobic iron-oxidizing bacteria (Emerson and Moyer 1997; Benz et al. 1998a) which exhibit high affinities for oxygen and can compete successfully with the chemical reaction. In the underlying anoxic zone, iron oxidation can be attributed to nitrate-reducing iron oxidizers (Straub and Buchholz-Cleven 1998; Hauck et al. 2001). A chemical oxidation of ferrous iron with nitrite was unlikely to occur since the nitrite concentration in the sediment never exceeded $1 \mu \mathrm{M}$. Another possibility is iron oxidation by 
anoxygenic phototrophic bacteria (Heising and Schink 1998; Straub et al. 1999). Since the euphotic zone of the sediment down to $3.5 \mathrm{~mm}$ depth was typically supplied with ample amounts of oxygen through oxygenic photosynthesis, phototrophic iron oxidizers would have to compete for ferrous iron with aerobic iron oxidizers. The outcome of this competition is not clear, but an assumed suppression of phototrophic iron oxidation would explain why efforts to count and isolate iron-oxidizing phototrophs from littoral sediments of Lake Constance yielded only very low numbers $(<10$ per $\mathrm{ml})$ of such bacteria (S. Heising, personal communication).

\section{Iron recycling}

The continuous sequence of rhythmic and irregular changes in light conditions leads to a redox cycle of iron within the sediment. Early in the morning, aerobic iron-oxidizing bacteria compete successfully at low oxygen concentration against chemical iron oxidation. With decreasing phototrophic activity in the afternoon, the oxidized iron represents an attractive electron acceptor for oxidation of low-molecular-weight organic compounds released, e.g., by the primary producers. Thus, both metabolic groups promote a rapid microscale cycling of iron, as has been shown also in microcosm experiments with a coculture of a lithotrophic ferrous-iron-oxidizing bacterium and a dissimilatory ferric-iron-reducing bacterium (Sobolev and Roden 2002). For a marine sediment, a repeated recycling of iron has been shown to occur in the dark. Ferric iron is reduced during anaerobic oxidation of organic carbon, and is subsequently reoxidized after exposure to oxygen at the sediment surface due to bioturbation (Canfield et al. 1993). A similar redox cycling of iron in saltmarsh sediments has been shown to be controlled by sulfate reduction and sediment oxidation as a consequence of annual cycles and short-term effects such as weather and tides (Kostka and Luther III 1995).

Iron cycling might be driven mainly by the iron species present in the porewater fraction of the sediment, which is present not only as free $\mathrm{Fe}^{2+}$ ions, but is also complexed by organic ligands (Luther III et al. 1992). The iron fraction analyzed in our study contains the amorphous or poorly crystalline species among the iron oxides that are easily accessible by mild acid extraction, e.g., ferrihydrite, $\mathrm{FeS}$ and $\mathrm{FeCO}_{3}$, and some iron leached from silicates (Moeslund et al. 1994). This fraction is considered to represent the biologically available portion of the insoluble iron phase and might be easily accessible for dissimilatory processes. The total amount of iron extractable from the sediment with concentrated acid is much higher.

\section{Significance of diurnal S-cycling for iron transformation}

Light-dependent changes also cause transformations of sulfur compounds that may play a major role in iron metabolism. The chemical microgradients of 
S-compounds and oxygen in euphotic layers of microbial mats are strongly influenced by the light-dependent photosynthetic activity of oxygenic and anoxygenic phototrophic bacteria, changing between anoxia and sulfide accumulation at night and oxygen supersaturation during the day (Revsbech et al. 1983). The activity of sulfate-reducing bacteria is also influenced diurnally owing to changes in temperature rather than to changes in oxygen concentration (Revsbech et al. 1983; Jorgensen 1994). The sulfide concentration influences the concentration of ferrous iron in the sediment by reduction of ferric iron and by precipitation of ferrous sulfide. In a marine sediment, reactive ferric iron and non-sulfur-bound ferrous iron is transformed almost completely to iron sulfides above $6 \mathrm{~cm}$ sediment depth, with most ferric iron reduction occurring in the upper $4 \mathrm{~cm}$ of the sediment; $63 \%$ of this iron reduction has been assigned to oxidation of reduced sulfur compounds (Thamdrup et al. 1994). Although the sulfur content of freshwater sediments is much lower than that of marine sediments, sulfur compounds probably play an important role as electron mediators also in freshwater systems.

\section{Seasonal changes in the redox state of iron compounds}

The proportion of ferrous iron in the surface sediment differed far more between sediment cores taken at different seasons than in the diurnal cycle, suggesting a more extended redox change over the year. The lowest ferrous iron concentrations were found in surface sediment collected in December; during May the concentration was higher and was highest in September. Obviously, ferric iron reduction was intense during spring and summer, whereas ferrous iron oxidation prevailed during late autumn and winter. Similar results were found for iron cycling in marine sediment of coastal bays at water depths of $1 \mathrm{~m}$ (Rozan et al. 2002) or $16 \mathrm{~m}$ (Thamdrup et al. 1994). The increasing ferrous iron content during spring and summer could be attributed to enhanced microbial or chemical ferric iron reduction caused by intensified import of organic matter into the sediment owing to the breakdown of algal blooms throughout the summer. In contrast, no annual cycle of iron concentrations and distribution was found in nonvegetated sediment of a freshwater wetland (Roden and Wetzel 1996).

Alterations in sunlight intensity over the year could also cause seasonal changes in the ferrous iron content of the surface sediment. During summer, the light intensity is high and reflection from the water surface is low because of the steep incident angle (Wetzel 2001). This might stimulate photochemical ferric iron reduction and cause higher ferrous iron concentrations at the sediment surface during summer. Light similar to sunlight both in intensity and spectral qualities and with an irradiance higher than $50 \mu \mathrm{E} \mathrm{m}^{-2} \mathrm{~s}^{-1}$ incident in seawater medium can cause photochemical ferric iron reduction only in the nanomolar range and enhance the supply of dissolved ferrous iron that supports phytoplankton growth (Miller and Kester 1994). 
An extended transition zone favors gradient organisms

In nature the light intensity changes quickly because of clouding, diurnally from night to day over several hours, and annually with the intensity and incident angle of sunlight. Oxygen concentration and penetration depth in the surface sediment reacts immediately to changes in illumination, and new steady-state situations are reached within a few minutes. This fluctuation of the oxic-anoxic interface is followed by a shift in the zonation and microbial transformation of all subsequent electron acceptors such as nitrate and sulfate. Results of this study showed that also up to $10 \%$ of the biologically available iron pool reacts to this change in the general redox state of the sediment during a $12 \mathrm{~h}$ day-night cycle. The varying spatial and temporal dimensions of these reactions create a large transition zone with shifting counter gradients of various compounds of varying concentration and redox state. This extended zone of potential microbial substrates with differences in pool sizes and reaction rates creates a large habitat for gradient organisms with a broad variety of temporary microniches for specific metabolic activities. This variety of niches sets the stage for the development of a broad organismic diversity in this environment, analogous to the so-called 'paradox of phytoplankton' (Hutchinson 1961).

\section{Acknowledgments}

This study was supported by grants of the Deutsche Forschungsgemeinschaft (DFG) in the special research program 'Lake Constance Littoral' (SFB 454). We thank Bianca Ruge for technical assistance with the oxygen microsensor measurements and Willi Nagl for helpful advice on statistical aspects.

\section{References}

Benz M., Brune A. and Schink B. 1998a. Anaerobic and aerobic oxidation of ferrous iron at neutral $\mathrm{pH}$ by chemoheterotrophic nitrate-reducing bacteria. Arch. Microbiol. 169: 159-165.

Benz M., Schink B. and Brune A. 1998b. Humic acid reduction by Propionibacterium freudenreichii and other fermenting bacteria. Appl. Environ. Microbiol. 64: 4507-4512.

Brune A., Emerson D. and Breznak J. 1995. The termite gut microflora as an oxygen sink: microelectrode determination of oxygen and $\mathrm{pH}$ gradients in guts of lower and higher termites. Appl. Environ. Microbiol. 61: 2681-2687.

Canfield D.E., Thamdrup B. and Hansen J.W. 1993. The anaerobic degradation of organic matter in Danish coastal sediments: iron reduction, manganese reduction and sulfate reduction. Geochim. Cosmochim. Acta 57: 3867-3883.

Carlton R. and Wetzel R.G. 1986. Distributions and fates of oxygen in periphyton communities. Can. J. Bot. 65: 1031-1037.

Chao T.T. and Zhou L. 1983. Extraction techniques for selective dissolution of amorphous iron oxides from soils and sediments. Soil Sci. Soc. Am. J. 47: 225-232. 
Cornell R.M. and Schwertmann U. 1996. The Iron Oxides - Structure, Properties, Reactions, Occurrence and Uses. 1st ed. VCH, Weinheim, Germany.

Ehrenreich A. and Widdel F. 1994. Anaerobic oxidation of ferrous iron by purple bacteria, a new type of phototrophic metabolism. Appl. Environ. Microbiol. 60: 4517-4526.

Emerson D. and Moyer C. 1997. Isolation and characterization of novel iron-oxidizing bacteria that grow at circumneutral pH. Appl. Environ. Microbiol. 63: 4784-4792.

Epping E. and Kühl M. 2000. The responses of photosynthesis and oxygen consumption to shortterm changes in temperature and irradiance in a cyanobacterial mat (Ebro Delta, Spain). Environ. Microbiol. 2: 465-474.

Fründ C. and Cohen Y. 1992. Diurnal cycles of sulfate reduction under oxic conditions in cyanobacterial mats. Appl. Environ. Microbiol. 58: 70-77.

Garcia-Pichel F., Mechling M. and Castenholz R.W. 1994. Diel migrations of microorganisms within a benthic, hypersaline mat community. Appl. Environ. Microbiol. 60: 1500-1511.

Ghiorse W.C. 1984. Biology of iron- and manganese-depositing bacteria. Annu. Rev. Microbiol. 38: $515-550$.

Glud R.N., Gundersen J.K., Røy H. and Jørgensen B.B. 2003. Seasonal dynamics of benthic $\mathrm{O}_{2}$ uptake in a semienclosed bay: importance of diffusion and faunal activity. Limnol. Oceanogr. 48: 1265-1276.

Hauck S.D., Benz M., Brune A. and Schink B. 2001. Ferrous iron oxidation by denitrifying bacteria in profundal sediments of a deep lake (Lake Constance). FEMS Microbiol. Ecol. 37: 127-134.

Heising S. and Schink B. 1998. Phototrophic oxidation of ferrous iron by a Rhodomicrobium vannielii strain. Microbiology 144: 2263-2269.

Hutchinson G.E. 1961. The paradox of the plankton. Am. Nat. 95: 137-146.

Jorgensen B.B. 1994. Sulfate reduction and thiosulfate transformations in a cyanobacterial mat during a diel oxygen cycle. FEMS Microbiol. Ecol. 13: 303-312.

Kostka J.E. and Luther G.W.III 1995. Seasonal cycling of Fe in saltmarsh sediments. Biogeochemistry 29: 159-181.

Kucera S. and Wolfe R. 1957. A selective enrichment method for Gallionella ferruginea. J. Bacteriol. 74: 344-349.

Kühl M. and Jørgensen B.B. 1994. The light field of microbenthic communities: radiance distribution and microscale optics of sandy coastal sediments. Limnol. Oceanogr. 39: 1368-1398.

Lovley D.R. 1997. Microbial Fe(III) reduction in subsurface environments. FEMS Microbiol. Rev. 20: $305-313$.

Lovley D.R., Coates J.D., Blunt-Harris E.L., Phillips E.J.P. and Woodward J. 1996. Humic substances as electron acceptors for microbial respiration. Nature 382: 445-448.

Lovley D.R. and Phillips E.J.P. 1986. Organic matter mineralization with reduction of ferric iron in anaerobic sediments. Appl. Environ. Microbiol. 51: 683-689.

Luther G.W.III, Kostka J.E., Church T.M., Sulzberger B. and Stumm W. 1992. Seasonal iron cycling in the salt-marsh sedimentary environment: the importance of ligand complexes with $\mathrm{Fe}(\mathrm{II})$ and $\mathrm{Fe}(\mathrm{III})$ in the dissolution of $\mathrm{Fe}(\mathrm{III})$ minerals and pyrite, respectively. Mar. Chem. 40: $81-103$.

Miller W.L. and Kester D. 1994. Photochemical iron reduction and iron bioavailability in seawater. J. Mar. Res. 52: 325-343.

Moeslund L., Thamdrup B. and Jørgensen B.B. 1994. Sulfur and iron cycling in a coastal sediment: radiotracer studies and seasonal dynamics. Biogeochemistry 27: 129-152.

Moraghan J. and Buresh R. 1976. Chemical reduction of nitrite and nitrous oxide by ferrous iron. Soil Sci. Soc. Am. J. 41: 47-50.

Nealson K. and Saffarini D. 1994. Iron and manganese in anaerobic respiration. Annu. Rev. Microbiol. 48: 311-343.

Nevin K.P. and Lovley D.R. 2000. Potential for nonenzymatic reduction of Fe(III) via electron shuttling in subsurface sediments. Environ. Sci. Technol. 34: 2472-2478.

Peiffer S. 1994. Reaction of $\mathrm{H}_{2} \mathrm{~S}$ with ferric oxides. In: Baker L.A. (ed.), Environmental Chemistry of Lakes and Reservoirs. American Chemical Society, pp. 371-390. 
Pfennig N. and Trüper H.G. 1992. The family Chromatiaceae. In: Balows A., et al. (eds), The Prokaryotes - A Handbook on the Biology of Bacteria: Ecophysiology, Isolation, Identification, Applications. Springer-Verlag, Berlin, Heidelberg and New York, pp. 3200-3221.

Pierson B.K. and Castenholz R.W. 1992. The family Chloroflexaceae. In: Balows A., et al. (eds), The Prokaryotes - A Handbook on the Biology of Bacteria: Ecophysiology, Isolation, Identification, Applications. Springer-Verlag, Berlin, Heidelberg and New York, pp. 3754-3774.

Pierson B.K., Parenteau M.N. and Griffin B.M. 1999. Phototrophs in high iron concentration microbial mats: physiological ecology of phototrophs in an iron-depositing hot spring. Appl. Environ. Microbiol. 65: 5474-5483.

Revsbech N.P. 1989. An oxygen microsensor with a guard cathode. Limnol. Oceanogr. 34: 474-478.

Revsbech N.P., Jørgensen B.B., Blackburn T.H. and Cohen Y. 1983. Microelectrode studies of the photosynthesis and $\mathrm{O}_{2}, \mathrm{H}_{2} \mathrm{~S}$, and $\mathrm{pH}$ profiles of a microbial mat. Limnol. Oceanogr. 28: 1062 1074.

Revsbech N.P., Jørgensen B.B. and Brix O. 1981. Primary production of microalgae in sediments measured by oxygen microprofile, $\mathrm{H}^{14} \mathrm{CO}_{3}^{-}$fixation, and oxygen exchange methods. Limnol. Oceanogr. 26: 717-730.

Roden E.E. and Wetzel R.G. 1996. Organic carbon oxidation and suppression of methane production by microbial $\mathrm{Fe}(\mathrm{III})$ oxide reduction in vegetated and unvegetated wetland sediments. Limnol. Oceanogr. 41: 1733-1748.

Roden E.E. and Wetzel R.G. 2002. Kinetics of microbial Fe(III)oxide reduction in freshwater wetland sediments. Limnol. Oceanogr. 47: 198-211.

Rozan T.F., Herszage J., Valdes L., Price K. and Luther G.W.III 2002. Iron-sulfur-phosphorus cycling in the sediments of a shallow coastal bay: implications for sediment nutrient release and benthic macroalgal blooms. Limnol. Oceanogr. 47: 1346-1354.

Sobolev D. and Roden E.E. 2002. Evidence for rapid microscale bacterial redox cycling of iron in circumneutral environments. Anton. Leeuw. Int. J. G. 81: 587-597.

Stookey L.L. 1970. Ferrozine - a new spectrophotometric reagent for iron. Anal. Chem. 42: 779-781.

Straub K.L., Benz M., Schink B. and Widdel F. 1996. Anaerobic, nitrate-dependent microbial oxidation of ferrous iron. Appl. Environ. Microbiol. 62: 1458-1460.

Straub K.L. and Buchholz-Cleven B. 1998. Enumeration and detection of anaerobic ferrous ironoxidizing, nitrate-reducing bacteria from diverse European sediments. Appl. Environ. Microbiol. 64: 4846-4856.

Straub K.L., Rainey F.A. and Widdel F. 1999. Isolation and characterization of marine phototrophic ferrous iron-oxidizing purple bacteria, Rhodovulum iodosum sp. nov. and Rhodovulum robiginosum sp. nov. Int. J. Syst. Bacteriol. 49: 729-735.

Straub K.L. and Schink B. 2003. Evaluation of electron-shuttling compounds in microbial ferric iron reduction. FEMS Microbiol. Lett. 220: 229-233.

Stumm W. and Morgan J.J. 1981. Aquatic Chemistry. Wiley, New York.

Szilágyi M. 1971. Reduction of $\mathrm{Fe}^{3+}$ ion by humic acid preparations. Soil Sci. 111: 233-235.

Tessenow U., Frevert T., Hofgärtner W. and Moser A. 1977. Ein simultan schließender Serienwasserschöpfer für Sedimentkontaktwasser mit fotoelektrischer Selbstauslösung und fakultativem Sedimentstecher. Archiv für Hydrobiologie / Supplementband 48: 438-452.

Thamdrup B. 2000. Bacterial manganese and iron reduction in aquatic sediments. In: Schink B. (ed.), Advances in Microbial Ecology, Vol. 16. Kluwer Academic/Plenum Publishers, New York, pp. 41-84.

Thamdrup B., Fossing H. and Jørgensen B.B. 1994. Manganese, iron, and sulfur cycling in a coastal marine sediment, Aarhus Bay, Denmark. Geochim. Cosmochim. Acta 58: 5115-5129.

Trüper H.G. and Pfennig N. 1992. The family Chlorobiaceae. In: Balows A., et al. (eds), The Prokaryotes - A Handbook on the Biology of Bacteria: Ecophysiology, Isolation, Identification, Applications. Springer-Verlag, Berlin, Heidelberg and New York, pp. 3583-3592.

Wetzel R.G. 2001. Limnology - Lake and River Ecosystems. 3rd ed. Academic Press, London. 
Widdel F., Schnell S., Heising S., Ehrenreich A., Assmus B. and Schink B. 1993. Ferrous iron oxidation by anoxygenic phototrophic bacteria. Nature 362: 834-836.

Zehnder A.J.B. and Stumm W. 1988. Geochemistry and biogeochemistry of anaerobic habitats. In: Zehnder A.J.B. (ed.), Biology of Anaerobic Microorganisms. Wiley, New York, pp. 1-38. 